\title{
Three Rare Variations in the Course of the Gonadal Artery
}

\author{
Tres Raras Variaciones en el Trayecto de la Arteria Gonadal
}

"Manimay Bandopadhyay \& **Anubha Saha

BANDOPADHYAY, M. \& SAHA, A. Three rare variations in the courseof the gonadal artery. Int. J. Morphol., 27(3):655-658, 2009.

SUMMARY: The gonadal arteries, lateral branches of the abdominal aorta, usually arise distal to the renal vessels. Knowledge of the origin and course of them, particularly their relationships with renal vessels, are important for uncomplicated surgical procedures on the posterior abdominal wall. So the relationship of the testicular artery and renal vessels were studied in 80 cadavers in Calcutta National Medical College, India and detected three rare variations. We have discussed the possible clinical implications and embryological explanation with review of literature of those variations.

KEY WORDS: Testicular artery; Renal artery; Gonadal artery.

\section{INTRODUCTION}

The testicular arteries are two long slender vessels that arise from the abdominal aorta, a little inferior to the renal artery. Right testicular artery runs anterior to the inferior vena cava, deep to the horizontal part of the duodenum. Left testicular artery runs behind inferior mesenteric vein and crosses genitofemoral nerve and ureter anteriorly to reach inguinal canal (Standring, 2005).

Notkovitch (1956) described three patterns of testicular artery. Type I: The artery after starting from the aorta descends directly without any contact with the renal vein. Type II: Origin of the artery is at a higher level than the renal vein and crosses the vein directly lying in front. Type III: The artery after arising at a lower level arches around the renal vein to descend. Knowledge of the course of the testicular artery as well as its relationship with the renal vein is important for surgical approach in this region (e.g. in renal transplantation) and for proper interpretation of angiographic procedures. The retroperitoneal dissection of the cadavers were done carefully to delineate the testicular vessels and to study their relationship with renal vessels. While doing so we got certain combinations of variations, which are rare in literature.

\section{CASE REPORT}

While dissecting intact formaldehyde preserved cadavers for undergraduate teaching in Calcutta National Medical College, kolkata, we were specifically studying the relationship of the gonadal artery with the renal vessels. While doing dissection of 80 cadavers, we have found following three variations:

Case 1. Left testicular artery after arising from the abdominal aorta distal to the origin of the renal artery, ascended up behind the left renal vein and then arched at its upper border to run downwards accompanying the testicular vein. Pattern on the opposite side were normal (Fig.1).

Case 2. Left renal vein in addition to the left suprarenal and gonadal vein had received an additional tributary, coming from posterior abdominal wall through the psoas major muscle. The left testicular artery had hooked this additional tributary to run along its normal course. The other side was normal (Fig. 2).

Case 3. The pattern of the left testicular artery were similar to the case $\mathrm{N}^{\circ} 2$, the only difference being on the right side. Drainage and origin of the right testicular vessels into the inferior vena cava and abdominal aorta were lower down than its normal site (Fig.3).

\footnotetext{
* Associate Professor, Department of Anatomy, Calcutta National Medical College, India.

** Post graduate trainee, Department of Anatomy, Mamata Medical College, Khammam, Andhra Pradesh, India.
} 




Fig. 1. The red arrow indicates the left testicular artery, arching around the left renal vein.

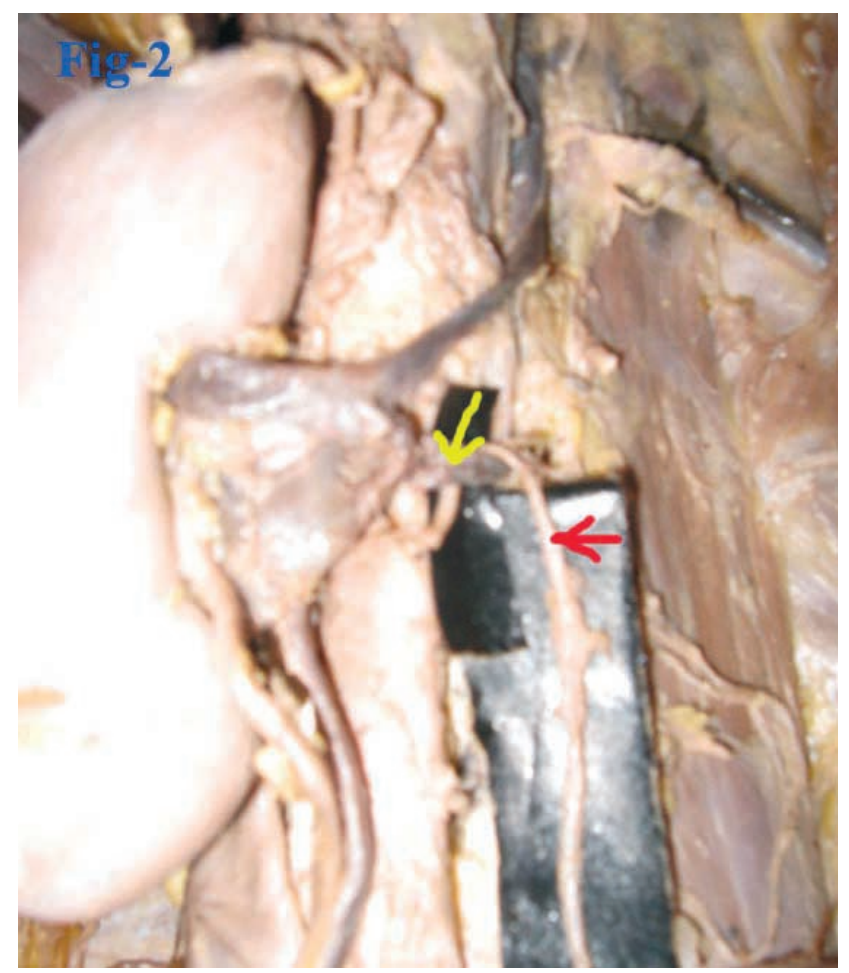

Fig. 2. Left kidney is retracted forwards to show the tributary draining into the left renal vein from the posterior abdominal wall (yellow arrow). The left testicular artery (red arrow) had looped around this tributary.

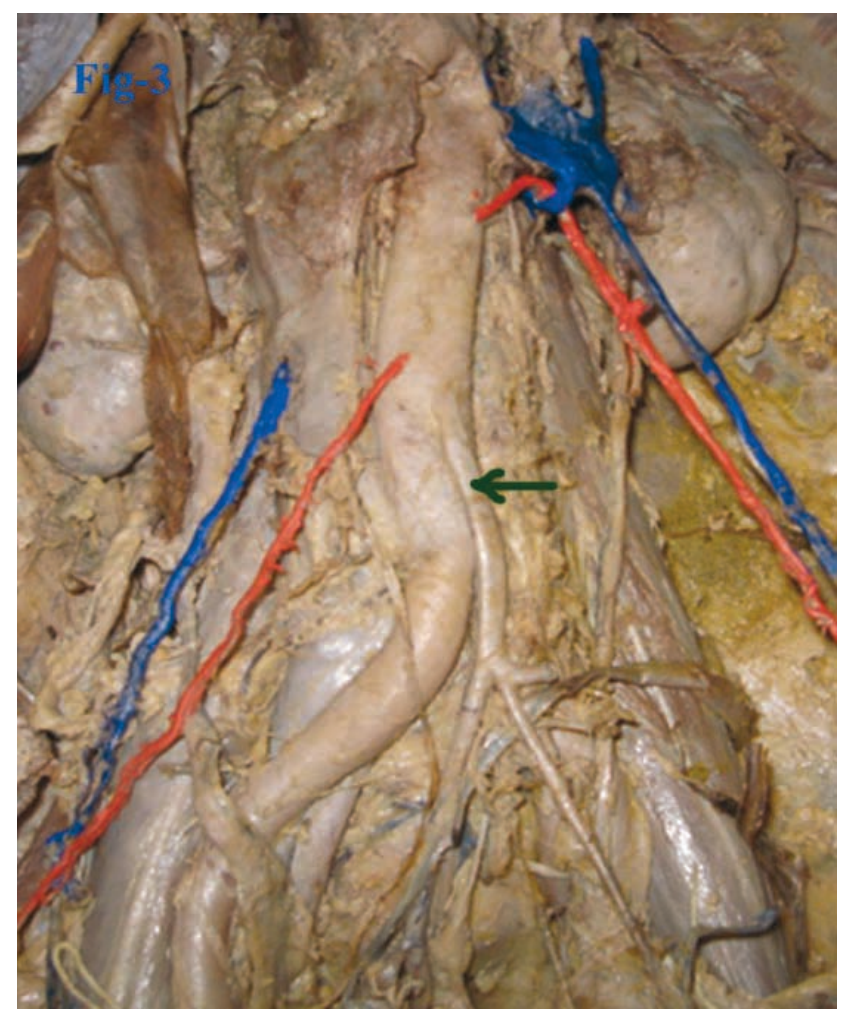

Fig. 3. Left testicular artery had arched around a tributary of the left renal vein and the right testicular vessels start and terminate at the level of the origin of the inferior mesenteric artery (green arrow).

\section{DISCUSSION}

Various workers had studied the relationship of the gonadal arteries. Notkovitch after dissecting 183 cadavers had found that left gonadal arteries arched over the left renal vein in $20.3 \%$ cases whereas that on the right side was $8 \%$. Naito et al. (2006) had found left testicular artery arching over the left renal vein in $6.7 \%$ cases and none on the right side after dissecting 59 male Japanese cadavers. In our study we had found three cases, all of which were Notkovitch type III variety, arching over the left renal vein or one of its tributary, the incidence being $3.8 \%(n=80)$. No such variations were detected on the right side. So this may indicate some sort of racial variation as absence of such a loop on the right corroborates that of Naito et al. (in Japanese) but not with that of Notkovitch (in USA).

Bergman et al. (2008) opines that there is no sex related difference in the course and origin of the gonadal arteries- indicating that this sort of a variation may be encountered in both male and female subjects during surgical and investigative procedures. 
Renal vein might also have multiple variations though the incidence is less than the renal arteries. Mirapeix et al. (1996) had reported a case where the right testicular artery passed through the bifid renal vein but in our case $\mathrm{N}^{\circ} 2$ and 3 the left testicular artery had hooked against a tributary of renal vein coming through psoas major. As per Begman et $a l$., the left renal vein may receive lumbar veins as tributaries. Baniel et al. (1995), while studying lumbar vessels, had found that in $43 \%$ cases they drained into the left renal vein. In the case $\mathrm{N}^{\circ} 2$ and 3 , the vein coming from the psoas major muscle was most likely a lumbar vein, which was being hooked by the left testicular artery.

Varicocele is a common condition involving $15 \%$ of healthy men and $40 \%$ of infertile men. It is common on the left side (85\%-90\%). There are various factors, which precipitate varicocele on the left side e.g. site and direction of drainage of the left gonadal vein, absence of valves, compression by the loaded sigmoid colon etc. As per Naito et al. and Skoog et al. (1997), looping of the left testicular artery might lead to compression of the left renal vein, which may precipitate engorgement of the left testicular veinleading to varicocele. The renal vein hypertension may lead to protenurea and hematuria in addition to varicocele. Compression of the left renal vein between the abdominal aorta and superior mesenteric artery isknown as Nutcracker syndrome which itself can produce various symptoms like hematuria (Chen et al., 2002). The incidence of this syndrome is underestimated as it is missed by the routine investigative procedures. According to Lelli et al. (2007), this type of arching testicular artery might be an additional cause of that syndrome as well as renal vein hypertension.

Gonadal arteries develop as lateral persistent splanchnic branches of the aorta that enter the mesonephros (Standring). These mesonephric arteries supply the developing gonads, suprarenal gland, the diaphragm and the kidney. Since developing gonads are placed cranial to the developing kidneys, the gonadal arteries are also placed cranially. With the gradual descent of the gonads new lower branches arise and the higher branches disappear. Lelli et $a l$., opines that when the developing gonadal artery arises caudal to the renal pedicle and the kidney ascends further, these Notkovitch type III varieties may develop. On the right side, in case $\mathrm{N}^{\circ} 3$, the mesonephric artery persisting as the gonadal artery was very lower down resulting a lower down gonadal artery. The subcentral veins forms the retro aortic parts of the left lumbar veins, which explains the arching of the left testicular artery around the left lumbar vein in case $\mathrm{N}^{\circ} 2$ and 3 .

BANDOPADHYAY, M. \& SAHA, A. Tres raras variaciones en el trayecto de la arteria gonadal. Int. J. Morphol., 27(3):655-658, 2009.

RESUMEN: Las arterias gonadales, ramas laterales de la aorta abdominal, usualmente surgen distales a los vasos renales. El conocimiento del origen y trayecto de estas, particularmente sus relaciones con los vasos renales, son importantes para procedimientos quirúrgicos sin complicaciones en la pared posterior del abdomen. La relación de la arteria testicular y los vasos renales fueron estudiados en 80 cadáveres en la Escuela Nacional de Medicina de Calcuta, India y se detectaron tres variaciones raras. Se discuten las posibles implicancias clínicas y explicaciones embriológicas, con la revisión de la literatura de estas variaciones.

PALABRAS CLAVE: Arteria testicular; Arteria renal; Arteria gonadal.

\section{REFERENCES}

Baniel, J.; Foster, R. S. \& Donohue, J. P. Surgical anatomy of the lumbar vessels: implications for retroperitoneal surgery. J. Urol., 153(5):1422-5, 1995.

Bergman, R. A.; Afifi, A. K. \& Miyauchi, R. Illustrated Encyclopedia of Human Anatomic Variation: Cardiovascular System: Renal, Splenic, and Testicular Veins, 2008. http://anatomyatlases.org/ AnatomicVariants/Cardiovascular/Text/Veins/ RenalSplenicTesticular.shtml.

Chen, Y. M.; Wang, I. K.; Ng, K. K. \& Huang, C. C. Nutcracker syndrome: an overlooked cause of hematuria. Chang Gung Med. J., 25(10):700-5, 2002.
Lelli, F.; Maurelli, V.; Maranillo, E. \& Valderrama-Canales F. J. Arched and retrocaval testicular arteries: a case report. Eur. J. Anat., 11(2):119-22, 2007.

Naito, M.; Terayama, H.; Nakamura, Y.; Hayashi, S.; Miyaki, T. \& Itoh, M. Left testicular artery arching over the ipsilateral renal vein. Asian J. Androl., 8(1):107-10, 2006.

Notkovich, H. Variations of the testicular and ovarian arteries in relation to the renal pedicle. Surg. Gynecol. Obstet., 103(4):487-95, 1956.

Mirapeix, R. M.; Sañudo, J. R.; Ferreira, B. \& DomenechMateu, J. M. A retrocaval right testicular artery passing 
through a hiatus in a bifid right renal vein. J. Anat., 189(3):689-90, 1996.

Skoog, S. J.; Roberts, K. P.; Goldstein, M. \& Pryor, J. L. The adolescent varicocele: what's new with an old problem in young patients?. Pediatrics, 100(1):112-21, 1997.

Standring, S. M. Gray's Anatomy. 39 $9^{\text {th }}$ Ed. London, Elsevier Churchill Livingstone, 2005. p.1306.
Correspondence to:

Dr. Manimay Bandyopadhyay, "Saila". 35/38/1C, Purbachal South Canal Road, Kasba, Kolkata.

West Bengal

INDIA

Email: manimaybandopadhyay@yahoo.co.in,

Received: 11-11-2008

Accepted: 14-04-2009 